\title{
Optimallaşdırma Məsələlərinin Həlli üçün Metaevristik Alqoritmlər
}

\author{
Ramiz Alıquliyev ${ }^{1}$, Günay Niftəliyeva ${ }^{2}$ \\ ${ }^{1,2}$ AMEA İnformasiya Texnologiyaları İnstitutu, Bakı, Azərbaycan \\ ${ }^{1}$ r.aliguliyev@gmail.com, ${ }^{2}$ gunayniftali@gmail.com
}

\begin{abstract}
Xülasə - Təbiət çox mürəkkəb problemləri özünəməxsus şəkildə həll etmək qabiliyyətinə malikdir. Otrafımızdakı problemlər real zaman daxilində getdikcə daha mürəkkəb hala gəlməkdədir. Təbiət bizə bu problemləri həll etmək üçün məntiqli və effektiv üsullar təklif edir.Mürəkkəb məsələlərin həllində təbiət optimizator rolunda çıxış edir. Bunları nəzərə alaraq, bu məqalədə təbiətdə gedən prosesləri imitasiya edən alqoritmlər müzakirə olunmuşdur. Burada təbiətə osaslanaraq yaradılmıs alqoritmlər qruplaşdırılmış və onlardan bir neçəsi nəzərdən keçirilmişdir.
\end{abstract}

Açar sözlor-optimallaşdırma, alqoritm, sürü

\section{GİRIS}

Hal-hazırda bir çox praktik məsələlər ən yaxşı həllin tapılması ilə əlaqədardır. Belə məsələlər optimallaşdırma üsulları vasitəsilə öz həllini tapır. Optimallaşdırma hər yerdə mövcuddur. Pul, resurslar və zaman həmişə məhdud olduğundan bu mənbələrdən səmərəli şəkildə istifadə olunması son dərəcə əhəmiyyətlidir. Optimallaşdırma məsələləri bir çox yollarla təsvir oluna bilər. Riyazi olaraq optimallaşdırma məsələlərini ümumi şəkildə aşağıdakı kimi yaza bilərik:

$x_{1}, x_{2}, \ldots, x_{n}$ dəyişənlərinin elə qiymətlərini tapmaq tələb olunur ki,

$$
z=f_{i}\left(x_{1}, x_{2}, \ldots, x_{n}\right) \rightarrow \max (\min ), i=1,2, \ldots, m
$$

funksiyası üçün

$$
\begin{aligned}
& h_{j}\left(x_{1}, x_{2}, \ldots, x_{n}\right)=0, j=1,2, \ldots, J \\
& g_{k}\left(x_{1}, x_{2}, \ldots, x_{n}\right) \leq 0, k=1,2, \ldots, K
\end{aligned}
$$

şəklində verilmiş məhdudiyyət şərtləri ödənsin.

Bir çox real-dünya optimallaşdırma məsələləri qeyri-xətti və multimodaldır. Multimodal optimallaşdırma məsələsi dedikdə, bir məqsəd funksiyası ilə bağlı bir neçə optimal həllin tapılması nəzərdə tutulur. Ümumi halda, ən yaxşı (optimal) həlli tapmaq asan iş deyil. Belə məsələlərin həll edilməsi üçün ilk istifadə olunan üsullar klassik riyazi üsullar olmuşdur. Hal-hazırda bir sıra məsələlər mövcuddur ki, onları klassik üsullarla həll etmək çətinlik törədir. Belə məsələlərin həlli üçün yeni alqoritmlərin işlənilməsinə ehiyac var. Məsələn, multimodal optimallaşdırma məsələləri üçün klassik alqoritmlər adətən pis işləyir, bu zaman diferensial təkamül kimi yeni alqoritmlər vasitəsilə bu məsələləri həll etmək mümkündür.

Metaevristik alqoritmlərin köməyilə bir çox optimallaşdırma məsələləri həll olunur. Metaevristik alqoritmlərdə əsas mənbə kimi təbiət qəbul olunur. "Metaevristik" sözü ilk dəfə 1986-cı ildə Fred Glover tərəfindən işlənilmişdir. Burada "evristika" sözü tapmaq, "meta" yüksək səviyyəli deməkdir. Son iyirmi il ərzində təbiətə əsaslanan alqoritmlər getdikcə daha populyar hala gəlmişdir. $\mathrm{Bu}$ alqoritmlər bir çox elm və mühəndislik sahələrində çox uğurla tətbiq olunmuşdur. Metaevristik alqoritmlər qlobal optimallaşdırma alqoritmlərinin, hesablama intellektinin və soft kompütinqin əsas sahələrindən birinə çevrilmişdir. $\mathrm{Bu}$ populyarlığın bir çox səbəbləri vardır. $\mathrm{Bu}$ alqoritmlərin tətbiqi sadədir və onların mürəkkəblik səviyyəsi aşağıdır. Bu alqoritmlər vasitəsilə klassik alqoritmlərin həll edə bilmədiyi böyük ölçülü optimallaşdırma problemlərini həll etmək mümkündür. Bu məqalədə bəzi populyar metaevristik alqoritmlər nəzərdən keçirilmişdir.

\section{OPTIMALLAŞDIRMA MӘSəLӘLӘRİ ÜÇÜN TӘBİӘTDӘN QAYNAQLANAN ALQORITTMLӘR}

Hal-hazırda yeni alqoritmlərin əksəriyyətini təbiət-əsaslı alqoritmlər təşkil edir, çünki bu alqoritmlər müxtəlif təbii proseslərə əsaslanır. $\mathrm{Bu}$ günə qədər təbiətə əsaslanaraq yaradılmış alqoritmlərin əksəriyyətində bioloji sistemin bəzi uğurlu xüsusiyyətlərindən istifadə olunmuşdur. Buna görə də, təbiət əsaslı alqoritmlərin böyük əksəriyyətini bioloji əsaslı alqoritmlər təşkil edir.

Bundan başqa, fiziki və kimyəvi proseslərə əsaslanan alqoritmlər də mövcuddur. Onlardan bəziləri, hətta musiqiyə əsaslana bilər[1].

Yuxarıdakı müzakirəyə əsasən biz bütün alqoritmləri dörd əsas kateqoriyaya bölə bilərik:

Sürü intellektinə əsaslanan;

$>$ Bioloji proseslərə əsaslanan (sürü intellektinə əsaslanmayan);

Fiziki və kimyəvi proseslərə əsaslanan;

$>$ Digər alqoritmlər.

Burada yetərincə yeni alqoritmləri nəzərdən keçirəcəyik. Genetik alqoritmlər kimi fundamental alqoritmlər yaxş1 məlum olduğundan onları burada araşdırmağa ehtiyac yoxdur. 
Təsnifat diqqət mərkəzində nəyin durduğundan və perspektivdən asılıdır[2]. Məsələn, əgər diqqət mərkəzində axtarış yolunun trayektoriyası durursa, onda alqoritmlər trayektoriya və çoxluq əsaslı alqoritmlər kimi təsnif oluna bilər. Ogər əsas diqqət maddələrin qarşılıqlı əlaqəsinə əsaslanarsa, onda alqoritmlər cəlbedici və qeyri-cəlbedici əsaslı alqoritmlər kimi təsnif olunur. İşıldaquş alqoritmi cəlbedici əsaslı alqoritmlərə ən yaxşı nümunədir, çünki işıldaquş işı̆̆ın cazibəsindən istifadə edərək digər işıldaquşları özünə cəlb edir, genetik alqoritmlərin isə heç bir aydın cazibəsi olmadığından onlar qeyri-cəlbedici əsaslı alqoritmlər hesab olunur. $\mathrm{Bu}$ aydın şəkildə onu göstərir ki, təsnifatlar faktiki perspektiv və motivlərdən asılıdır.

\section{SÜRÜ İNTELLEKTINӘ ĐSASLANAN OPTIMALLAŞDIRMA ALQORITTMLORİ}

Sürü intellekti bəzi sadə qaydalara riayət edən qarşılıqlı əlaqədə olan subyektlərin davranışlarını ortaya çıxaran kollektivə aiddir. Bir çox alqoritmlər təbiətdə sürü intellekti sistemlərindən ilham alınaraq işlənilmişdir. Sürü intellektinə əsaslanan alqoritmlərdə qarışqa, arı kimi sosial həşərat, eləcə də balıq və quş kimi digər heyvan qruplarının kollektiv davranışlarından istifadə olunmuşdur. İşıldaquş alqoritmi işıldaquş sürülərinin yanıb-sönən (sayrışan) davranışına, yarasa alqoritmi qida axtaran yarasaların səs lokasiyasına, ququ quşu alqoritmi isə ququ quşu növlərinin məqsədli parazitizminə əsaslanır. Qarışqa sürüsü alqoritmi sosial həşəratların qarşılıqlı əlaqəsindən istifadə edir, arı alqoritmləri isə bal arılarının qida axtarışı hərəkətinə əsaslanır.

Sürü intellektinə əsaslanan alqoritmlər ən məşhur və geniş istifadə olunan alqoritmlərdəndir. Bu məşhurluğın səbəbləri çoxdur. Onlardan biri ondan ibarətdir ki, sürü intellektinə əsaslanan alqoritmlər bir çox subyektlər arasında məlumat mübadiləsini həyata keçirir, belə ki, iterasiyalar zamanı özünü təşkil, ortaq təkamül və öyrənmə bu alqoritmlərin yüksək effektivliyini təmin edir. Başqa bir səbəbi ondan ibarətdir ki, bir çox subyektlər asanlıqla paralelləşə bilir, beləcə böyük ölçülü optimallaşdırma məsələləri reallaşdırma baxımından daha praktik hala gəlir. Sürü intellektinə əsaslanan alqoritmlərə işıldaquş, qarışqa, arı, canavar, meymun, pişik sürüsü və s. kimi alqoritmləri misal göstərə bilərik. Onlardan bir neçəsi aşağıda nəzərdən keçirilmişdir.

İşıldaquş alqoritmi. İşıldaquş alqoritmi 2007-ci ildə Dr. Xin-She Yang tərəfindən işlənilib və tropik iqlim bölgələrindəki işıldaquşların davranışlarını əsas götürən optimallaşdırma alqoritmidir [3]. Bu alqoritmin anlaşılması və tətbiqi sadədir.

Bir işıldaquş digər işıldaquşların diqqətini çəkmək üçün işıqlarını yandırıb söndürərək bundan bir siqnal sistemi kimi istifadə edir. Yanıb-sönən işıqların yaranmasına səbəb olan biokimyəvi prosesin detalları və real məqsədi elm dünyasında hələ müzakirə mövzusu olmasına baxmayaraq, bir çox tədqiqatçılar yanıb-sönən işıqların işıldaquşun yoldaşlarını tapmaqda, ovlarının diqqətini çəkmək və mövcud təhlükələrdən özlərini qorumaqda köməkçi vasitə olduğunu əsas götürürlər [3].

İş1ldaquş alqoritmində 3 əsas qaydadan istifadə olunur:
1. İşıldaquşlar bircinsdirlər, belə ki, bir işıldaquş digər işıldaquşu onun cinsindən asıll olmayaraq cəlb edir.

2. Cəlbedicilik parlaqlığa mütənasibdir və böcəklər arasındakı məsafə artdıqca cəlbedicilik azalır. İki işıldaquşdan daha az parlaq olan daha çox parlaq olana doğru hərəkət edir. Ogər müəyyən işıldaquşa nəzərən daha parlağ 1 yoxdursa, o təsadüfi hərəkət edir.

3. İşıldaquşun parlaqlığı məqsəd funksiyası ilə müəyyən olunur.

Fərz edək ki, $i$-ci işıldaquşun hərəkəti daha parlaq olan $j$ ci işıldaquş tərəfindən cəlb olunur və onun hərəkəti

$$
x_{i}^{t+1}=x_{i}^{t}+\beta_{0} e^{-\gamma_{i j}^{2}}\left(x_{j}^{t}-x_{i}^{t}\right)+\alpha \varepsilon_{i}^{t}
$$

ilə müəyyən olunur. Buradaikinci hədd cəlb edicilik ilə bağlıdır. $\quad r_{i j} i$ və $j$-ci işıldaquşlar arasındakı məsafə, $\beta_{0}$ $r=0$ məsafəsində cəlbedicilikdir. Nəzəri olaraq $\gamma \in[0, \infty)$ aralığında qiymət alan parametrdir, lakin praktik olaraq adətən $\gamma=O(1)$ qəbul olunur. Üçüncü həddə $\alpha$ təsadüflik parametri və $\varepsilon_{i}^{t}$ Qauss paylanmasından olan təsadüfi ədədlər vektorudur. $\beta_{0}=0$ olarsa, bu sadə təsadüfi gəzintidir.

İşıldaquŞ alqoritmi NP-çətin həll olunan məsələlərin həllində on effektiv üsuldur.

Qarışqa alqoritmi. Qarışqa alqoritmi qarışqaların inisial davranışlarının riyazi modellorinə əsaslanır [4]. Bu alqoritm $\mathrm{X}$. Dorigo və başqaları tərəfindən işlənmişdir. Qarışqa ətraf şəraitə görə qida mənbəyi ilə yuvası arasında gedə biləcəyi yolları müəyyən edir. Müəyyən olunan yollardan birindən ilk keçən qarışqa yola feromon adlanan qoxulu maddə buraxır. Ogər yol qisa olarsa, bu qoxu daha six olur və digər qarışqalar da eyni şəkildə yola davam edirlər. İki yolun kəsişdiyi nöqtədə qarışqa hansı yolla gedəcəyini müəyyənləşdirir. Hansı yolu seçəcəyini ilk əvvəl qoxu miqdarının sıxlığına əsasən, ikinci olaraq isə təsadüfi meyara görə müəyyən edir. Bu təsadüfi seçimin məqsədi isə bütün qarışqaların eyni yolla getməsinə maneə törədərək yeni və daha qisa yolları kəşf etməkdir (şəkil 1).

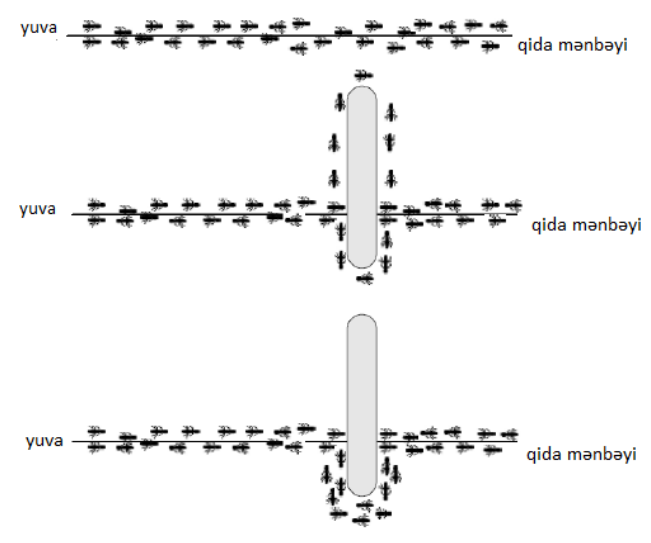

Şəkil 1. 
Qarışqa alqoritmində qarışqalar sadə hesablayıcı subyektlərdir. Alqoritm iterativ olaraq aparılır. Alqoritmin hər iterasiyasında qarışqa $x$ nöqtəsindən $y$ nöqtəsinə doğru müəyyən ehtimalla hərəkət edir. $k$ qarışqasının $x$ nöqtəsindən $y$ nöqtəsinə getmə ehtimalı iki parametrdən asılıdır: $\eta_{x y}$ keçidin (hərəkətin) cəlbediclik parametrindən və $\tau_{x y}$ keçidin iz səviyyəsindən (feromon miqdarından). $k$-cı qarışqanın $x$ nöqtəsindən $y$ nöqtəsinə getmə ehtimalı aşağıdakı düsturla hesablanır:

$$
p_{x y}^{k}=\frac{\left(\tau_{x y}^{\alpha}\right)\left(\eta_{x y}^{\beta}\right)}{\sum_{z \in \text { allowed }_{y}}\left(\tau_{x z}^{\alpha}\right)\left(\eta_{x z}^{\beta}\right)}
$$

burada $\tau_{x y} x$ nöqtəsindən $y$ nöqtəsinə keçid zamanı qoyulan (depozit olunan) feromon miqdarı, $\quad \alpha \geq 0 \tau_{x y}$-in əhəmiyyətliliyini müəyyən edən parametr, $\eta_{x y} x y$ keçidinin cəlbediciliyidir və $1 / d_{x y}$ ilə müəyyən olunur $\left(d_{x y} x\right.$ və $y$ nöqtələri arasında məsafədir). $\beta$ isə $\eta_{x y}$-in əhəmiyyətliliyini müəyyən edən parametrdir. $\tau_{x z}$ və $\eta_{x z}$ digər mümkün keçidlərin uyğun olaraq iz səviyyəsi və cəlbediciliyidir.

Feromon yenilonmosi. Bütün qarışqalar keçidlərini tamamladıqdan sonra feromon miqdarları yenilənir. İlk olaraq bütün yollardakı feromonlar təyin olunan nisbətdə buxarlandırılır. Daha sonra qarışqaların getmiş olduqları yollardakı feromon miqdarları o yolu istifadə edən qarışqanın ümumi yol uzunluğu ilə tərs mütənasib olaraq artırılır.

Beləliklə, daha qisa yola sahib qarışqaların istifadə etdikləri yollardakı feromon miqdarları daha çox artım göstərir.

$$
\begin{gathered}
\tau_{x y} \leftarrow(1-\rho) \tau_{x y}+\sum_{k} \Delta \tau_{x y}^{k} \\
\Delta \tau_{x y}^{k}=\left\{\begin{array}{lc}
1 / L_{k} & k \text { qarışqası } x y \text { yolundan istifadə etdikdə } \\
0 & \text { digər hallarda }
\end{array}\right.
\end{gathered}
$$

burada $\Delta \tau_{x y}^{k} k$-cı qarışqanın $x y$ yolunun vahid uzunluğunda qoyduğu feromonun miqdarı, $\rho(0 \leq \rho \leq 1)$ feromon buxarlanma əmsalı, $L_{k}$ qarışqanın getmiş olduğu yolun ümumi uzunluğudur.

Qarışqalar dəyişən feromon miqdarlarından asılı olaraq hər iterasiyada keçidlərini dəyişirlər. Beləliklə, davamlı olaraq q1samüddətli keçidləri tapmaq məqsədi qoyulur.

Qarışqaların optimal sayı. Qarışqaların sayının artırılması həldə yaxşılaşmaya səbəb olur. Lakin hesablamaları artırdığ 1 üçün qarışqaların sayının çox artırılması əməliyyatların artmasına səbəb olur. Səyyah satıcı məsələlərində edilən sınaqlar nəticəsində qarışqaların sayının şəhərlərin sayına bərabər seçilməsi nəticəsinə gəlmişlər. Qarışqaların sayı problemin ölçüsündən və tətbiq sahəsindən asılı olaraq dəyişir.

\section{BİOLOJİ PROSESLӘRӘ ӘSASLANAN ("SÜRÜ" İNTELLEKTINO ӘSASLANMAYAN) OPTIMALLAŞDIRMA ALQORITMLӘRİ}

Aydındır ki, sürü intellektinə əsaslanan alqoritmlər bioloji əsaslı alqoritmlərin geniş sinfinə daxildir. Bioloji əsaslı alqoritmlər təbiət əsaslı alqoritmlərin böyük əksəriyyətini təşkil edir.

Təbiət əsaslı alqoritmlərin hamısı bioloji əsaslı deyil və onlardan bəziləri, fiziki və kimyəvi proseslərə əsaslanan alqoritmlərdir. Bioloji əsaslı alqoritmlərin çoxu birbaşa sürü davranışından istifadə etmir. Məsələn, gül alqoritmi və ya gül tozlanma alqoritmi bioloji əsaslı sürü intellektinə əsaslanmayan alqoritmdir. Gül alqoritmi çiçəkləyən bitkilərin tozlanma xarakteristikasını təqlid etməyə çalışır və gülü bəzi tozlandırıcı həşəratlarla əlaqələndirir. Bioloji proseslərə əsaslanan alqoritmlərə bulud modeli, gül bitkilərinin tozlanma, invaziv alaq otlarının optimallaşdırılması, böyük qızıl balıq alqoritmi və s. daxildir.

Böyük qızıl balıq alqoritmi: Qızıl balıq fenomeni Şimalı Amerikada baş verən ən böyük illik hadisələrdən biridir və bu zaman milyonlarla qızıl balıq kürü tökmək üçün dağ axınları vasitəsilə miqrasiya edirlər. Bu canlılar canlı orqanizmlər üçün əsas qida mənbəyi olduğundan onlar keçid axını zamanı bəzi ağır təhlükələrlə qarşılaşa bilərlər. Ac boz ayılar, balıqçılar və şəlalələr onların qarşılacağı ən böyük təhlükələrdəndir. Q1zıl balıqlar ac ayılar üçün ən mühüm qidalardan biridir. Ayılar balıqların intensivliyi yüksək olan əraziləri tapmaq üçün birbiri ilə ünsiyyət qururlar. Oslində onlar qızıl balıq ovu üçün sürü intellekti qaydalarını izləyirlər. İnsanlar qızıl balıqların digər ən mühüm ovçularından biridir. $\mathrm{Bu}$ balıqçılar tez-tez qızıl balıqların ovu üçün kifayət qədər yaxşı şəraiti olan Alyaskada toplaşırlar. İnsanlar qızıl balıqların kəmiyyət və keyfiyyət baxımından yüksək olduğu məkanları tapmaq üçün bəzi evristik metodları təqlid edirlər. Onlar balıqların tam keçid məkanının araşdırılması üçün kəşfiyyat gəmilərindən istifado edirlor.

Təcrübələr göstərir ki, insanların ovçuluq təcrübəsi həqiqətən effektivdir, belə ki, onlar ilk növbədə bütün sahəni araşdırmaq üçün onu althissələrə ayırır, sonra isə intensiv məkanlarda inteqrasiya edirlər. Miqrasiya zamanı qızılbalığın həyatını təhdid edən bir çox başqa elementlər də var. Miqrasiyanın əvvəlində onlar instinktlərin və bəzi stoxastik şərhlərin köməyi ilə bir neçə yarımqrupa bölünürlər. Bu yarımqrupların hər biri öz hədəflərinə çatmaq üçün müxtəlif yollar seçir. Onlardan bəziləri okean, göl və gölməçələrə doğru hərəkət edərkən, digərləri meşə keçidlərini seçirlər. Burada, bu anlayışdan yeni intellektual optimallaşdırma alqoritminin yaradıması üçün istifadə edilmişdir.

Alqoritm: Böyük q1zıl balıq alqoritmində (BQBA) iki müstəqil təkamül operatorundan istifadə olunur. $\mathrm{Bu}$ operatorlardan biri meşə regionları və dağ kanyonlarında hərəkət edən q1zıl balıqlara məxsusdur. Digəri isə okean, göl və gölməçələrdə hərəkət edən qizıl balıqlara məxsusdur. Yuxarıda qeyd etdiyimiz kimi, q1zıl balıqlar keçidləri instinktləri əsasında seçirlər. Lakin təcrübələr göstərir ki, bu canlılar kanyon və meşə keçidlərinə nəzərən göl və nohurlardan keçməyə daha çox üstünlük verirlər. Boz ayılar dağ kanyonları və meşələrdə q1zıl balıqları ovlayarkən, 
kommersiya ovçuları bu balıqları okean və gölməə̧ələrdə ovlayırlar. Bu iki əsas ovçulardan hər biri yüksək keyfiyyət ilə qızıl balıq ovu üçün müxtəlif üsullardan istifadə edirlər. Bu alqoritmin əsas addımları aşağıda verilmişdir[5]:

Innisiallaşdırma: Təklif olunmuş alqoritmdə hər bir potensial həll regionda (alt qrupda qizıl balıqların miqdarı) qızıl balıq intensivliyini təmsil edir. Başqa sözlə, yüksək qızıl balıq intensivliyi olan regionda daha yüksək yararlılıq ilə həll əldə olunur. Aşağıdakı bərabərlik axtarış fəzası ilə əlaqədar olaraq təsadüfi həlləri başlatmaq üçün lazım olan proseduranı ifadə edir:

$$
\text { Initial solution }=l b+\text { rand } *(u b-l b)
$$

burada $l b$ və $u b$ ən aşağ aralığında müntəzəm paylanmış təsadüfi ədəddir.

Həllərin inisializasiyasından sonra optimallaşdırma proseduru başlanır. Optimallaşdırma prosesinin əvvəlində başlanğıc həllərin hamısı (qızılbalıq altqrupları) onların miqrasiyası (iterativ hərəkətləri) üçün hazırlanır. Buradan aydındır ki, hər bir miqrasiya dövrü təbii miqrasiya fenomeninə ekvivalentdir.

Miqrasiya cı̆̆ırlarının seçilməsi: Miqrasiyadan əvvəl qızıl balıqlar instinktləri əsasında yolları seçirlər. Bu proses riyazi olaraq aşağıda təsvir olunmuşdur:

$$
\text { Solution's Sharing: }\left\{\begin{array}{l}
N_{p_{1}}=\left[\mu * P_{s}\right] \\
N_{p_{2}}=P_{s}-N_{p_{1}}
\end{array},\right.
$$

burada $N_{p_{1}}$ okean və gölməçələrdən keçid edən q1zıl balıq qruplarının sayı $N_{p_{2}}$ meşələrdən və dağ kanyonlarından keçid edən qızıl balıq qruplarının sayı, $P_{s}$ miqrasiyada iştirak edən bütün qızıl balıq qruplarının sayı və $\mu$ qızıl balıq instinktini əks etdirən mübadilə amilidir. Göründüyü kimi, təklif olunan formula stoxastik həllin yerdəyişmələri üçün olan strategiyadır. Mübadilə prosesinin tətbiqindən sonra bu altqruplar öz cı̆̆grlarına (təkamül operatoru) daxil olurlar. Bu yollardan keçən zaman müxtəlif təhlükələrlə qarşı1laşa bilərlər. Aşağıda keçidi qət etmənin detalları verilmişdir.

Göl vo gölmaçəlardon keçid: İlk operator insan ovçuluğunu modelləşdirir. İnsanlar keçid üstünlüyünü (həll fəzasını) araşdırmaq üçün kəşfiyyat gəmilərindən istifadə edir. $\mathrm{Bu}$ kəşfiyyat gəmiləri bacardıqları qədər ən yaxşı şəkildə keçidi araşdırmaq üçün bəzi riyazi qrafik axtarışı (intellektual diversifikasiya metodikası) tətbiq edirlər. Bu kəşfiyyat riyazi olaraq aşağıdakı şəkildə ifadə olunur:

$$
\left\{\begin{array}{l}
X_{N}=X_{F}+\delta\left(t,\left(u b-X_{F}\right)\right) \\
X_{N}=X_{F}+\delta\left(t,\left(X_{F}-l b\right)\right)
\end{array}\right.
$$

burada $t$ cari iterasiya sayını, $X_{N}$ yeni aşkar regionu (yeni həll) və $X_{F}$ kəşfiyyat gəmilərinin (keçmiş həll) keçmiş regionunu göstərir.

$$
\delta(x, y)=y * \operatorname{rand} *\left(1-\frac{x}{T}\right)^{b}
$$

$T$ maksimum iterasiya sayı, $b$ 1-dən böyük olan təsadüfi ədəd və rand $[0 ; 1]$ aralığında müntəzəm paylanmış təsadüfi ədəddir.

Qalan gəmilər (kommersiya balıqçıları kimi tanınan) qızıl balıqların ovu üçün daha yaxşı əraziləri tapmaq üçün kəşfiyyat gəmiləri və digər kommersiya balıqçıları ilə ünsiyyət qururlar. Daha sonra onlar qızıl balıqların intensivliyi yüksək olan ərazilərdə toplaşırlar. Balıqçı qrupları iki əsas ovçu gəmilərindən və seçilmiş gəmilərdən ibarətdir. İlk olaraq, əsas ovçular məqbul qızıl balıq intensivliyi (həll yararlılığı) olan əraziləri tapırlar. Bundan sonra onlar daha intensiv əraziləri (yüksək yararlılıq ilə həll) tapmaq üçün yaxın əraziləri istismar etmək üçün seçilmiş agentləri məlumatlandırırlar. $\mathrm{Bu}$ istismar riyazi olaraq (aşağıdakı şəkildə ifadə olunur:

$$
X_{R}=\beta *\left(X_{M 1}-X_{M 2}\right)+X_{M 1}
$$

burada $\beta[0 ; 1]$ aralığında müntəzəm paylanmış təsadüfi ədəd, $X_{R}$ seçilmiş agentlər tərəfindən yeni aşkar həll, $X_{M 1}$ ilk əsas ovçular tərəfindən əldə olunmuş həll, $X_{M 2}$ digər ovçular tərəfindən əldə olunmuş həldir.

Dağ kanyonlarından vo meşalordon keçid: kinci operator boz ayıların ovçuluq metodologiyasını modelləşdirir. Digər heyvanlar kimi, boz ayılar da daha yüksək qızıl balıq intensivliyi ilə ərazi tapmaq üçün bir-biri ilə ünsiyyət qururlar. Onların ovçuluq metodu həqiqətən sadədir. Məqbul ərazini tapdıqda bir-birlərinə xəbər verirlər. Bundan sonra boz ayı qrupları ən yaxşı məkana yaxınlaşır və yaxın ərazilərdə axtarış edirlər. Ogər onlar yüksək qızıl balıq intensivliyi olan ərazini tapırlarsa, onlar digər ayıları məlumatlandırır. Oks halda onlar bölgəni tərk edir və lokal axtarışı davam etdirirlər. Ayı ovçuluğu prosedurasının əsas mənfi cəhətlərindən biri müstəqil müxtəlif kəşfiyyat işlərinin olmamasıdır. Ayı ovçuluğu metodologiyası riyazi şəkildə aşağıdakı düstur vasitəsilə ifadə olunur:

$$
X_{B}=\cos (\varphi) *\left(B_{R}-L_{R}\right)+B_{R}
$$

burada $X_{B}$ yeni aşkar olunmuş bölgəni, $B_{R}$ ovçu qrupunun ən yaxşı hesab etdiyi bölgəni, $L_{R}$ ayıların lokal istismarı yerinə yetirməyə qərar verdiyi cari bölgəni və $\varphi[0 ; 360]$ aralı̆̆ında yerləşən bucaqdır. $\cos (\varphi)$ ayıları hədəflərinə doğru istiqamətləndirir.

Kürü tökmək üçün yenidon qruplaşma: Miqrasiyanın sonunda sağ qalmış qızıl balıqlar kürü tökmək üçün lazım olan məkanda birləşirlər. Alqoritmdə bu təbii hadisə konteyner vasitəsilə modelləşdirilir. Qızıl balıqlar cığırları (operatorun çıxışı) keçdikdən sonra qızıl balıq altqrupları (həllər) unikal konteynerdə toplaşır. Başqa sözlə, qərarlar (həllər) hər iki operatordan hasil olunur və unikal çoxluğu təşkil edir. Bu vəziyyətdə birinci iterasiyanın sonuna çatır. Kürü tökmək üçün iqlim və istəkdə dəyişiklik daha bir miqrasiya başlamaq üçün qalan qızıl balıqları vadar edən iki əsas motivlərdəndir. 
Bu daimi miqrasiyanın davamlılı̆ğ bu alqoritmi güclü iterativ optimallaşdırma alqoritminə çevirir.

Bulud modeli alqoritmi. Buludlar dünyanın qlobal xüsusiyyətlərindən biridir. Onlar havada su buxarının qatılaşması nəticəsində yaranmış su damcılarıdır. Dinamik hərəkət prosesi, yay1lma və bulud bərpa prosesləri təbii kompleks hadisələrdir. Bunu qeyd edək ki, ilk olaraq yer bir çox laylardan ibarət olan bütöv bir məkan kimi qəbul olunur və hər sahənin öz rütubət qiyməti və hava təzyiqi var. Ümumi biliklərə əsasən, rütubət qiyməti yüksək olan sahələr bulud əmələ gətirir və sahələr arasında olan hava təzyiqi fərqi hava axını yaradır, yaranmış buludlar aşağı hava təzyiqi olan ərazilərə doğru uçurlar və onlar hərəkət prosesində ətraf ərazilərin təzyiqinə əsasən toplaşır və ya yayılırlar. Buludların sadə şəkildə yaranma, hərəkət və yayılma davranışlarının modelləşdirilməsi nəticəsində "Atmosfer buludu modeli optimallaşma" alqoritmi Yan və Hao tərəfindən 2012-ci ildə işlənilmişdir [6].

\section{FIZIKIKI VӘ KIMYЭVİ PROSESLӘRӘ ӘSASLANAN ALQORITMLOR}

Metaevristik alqoritmlərin hamısı bioloji əsaslı deyil, onların bəziləri fiziki və kimyəvi proseslərə əsaslanır. Bioloji əsaslı olmayan alqoritmlər elektrik yükü, ağırlıq, çay sistemləri və s. daxil olmaqla fizika və kimya qanunlarını təqlid edərək işlənmişdir. Müxtəlif təbii sistemlər bu kateqoriya ilə əlaqəlidir, biz hətta onları bir çox lazım olmayan altkateqoriyalara bölə bilərik.

Fizika və kimya iki müxtəlif fənn olmasına baxmayaraq, fizika və kimya əsaslı alqoritmləri daha bir altkateqoriyaya bölmək faydalı deyil. Çünki fundamental qanunların çoxu eynidir, buna görə də biz onları sadəcə olaraq fizika və kimya əsaslı alqoritmlər kimi qruplaşdırırıq. Fizika və kimya proseslərinə əsaslanan alqoritmlərə Qravitasiya axtarış alqoritmi, Böyük partlayış-Böyük böhran, Qara dəlik, Qalaktika əsaslı axtarış alqoritmləri və s. daxildir.

Qravitasiya axtarış alqoritmi. Qravitasiya axtarış alqoritmi (QAA) cazibə qanununa əsaslanır [7]. Maddi nöqtələr obyektlər hesab olunur və onların fəaliyyəti kütlələri ilə ölçülür. Bütün obyektlər ağırlıq qüvvələri ilə bir-birini cəzb edir və bu qüvvə ağır kütləli obyektlərə tərəf bütün obyektlərin qlobal hərəkətinə səbəb olur.

QAA-da hər bir obyektin dörd əsas xüsusiyyəti var: mövqe, ətalət kütləsi, aktiv qravitasiya kütləsi və passiv qravitasiya kütləsi. Obyektin mövqeyi məsələnin həllinə uyğun gəlir və qravitasiya və ətalət kütlələri yararlılıq funksiyasından istifadə etməklə müəyyən olunur.

Başqa sözlə, hər bir kütlə həlli təsvir edir və alqoritm normal qravitasiya və ətalət kütləsinin tənzimlənməsi üzrə hərəkət edir. Zaman keçdikcə kütlələrin ən ağır kütlə tərəfindən cəzb olunması gözlənilir. Bu kütlə axtarış fəzasında optimal həll olacaq. Başqa sözlə, hər bir kütlə həlli təqdim edir və alqoritm normal qravitasiya və ətalət kütləsinin tənzimlənməsi üzrə hərəkət edir. Zaman keçdikcə kütlələrin ən ağır kütlə tərəfindən cəzb olunması gözlənilir. Bu kütlə axtarış fəzasında optimal holl olacaq.
QAA kütlələrin təcrid olunmuş sistemi hesab oluna bilər. $\mathrm{Bu}$ cazibə və hərəkətin Nyuton qanunlarına tabe olan kütlələrin kiçik süni dünyasına oxşayır. Daha dəqiq desək, kütlələr aşağıdakı qanunlara tabe olur:

Cazibə qanunu: Hər bir maddi nöqtə digər maddi nöqtələri cəzb edir və iki maddi nöqtə arasında olan qravitasiya qüvvəsi kütlələri hasili ilə düz və aralarındakı məsafə $R$ ilə tərs mütənasibdir. Burada, $R^{2}$ əvəzinə $R$-dən istifadə olunmuşdur.

Horəkət qanunu: Hər hans1 kütlənin cari sürətiəvvəlki sürət fraksiyası və sürət variasiyasının cəminə bərabərdir. Sürət variasiyası və ya hər hansı kütlə təcili ətalət kütləsi tərəfindən bölünmüş sistemdə təsir edən qüvvəyə bərabərdir.

Fərz edək ki, $N$ maddi nöqtədən (kütlədən) ibarət sistem verilmişdir. $i$-ci maddi nöqtənin mövqeyi aşağıdakı kimi təyin olunur:

$$
x_{i}=\left(x_{i}^{1}, \ldots, x_{i}^{d}, \ldots, x_{i}^{n}\right), i=1,2, \ldots, N .
$$

burada $x_{i}^{d} d$-ci ölçüdə $i$ maddi nöqtənin mövqeyidir.

Müəyyən $t$ zamanında $j$-ci kütlədən $i$-ci kütləyə təsir edən qüvvə aşağıdakı kimi müəyyən olunur:

$$
F_{i j}^{d}(t)=G(t) \frac{M_{p i}(t) \times M_{a j}(t)}{R_{i j}(t)+\varepsilon}\left(x_{j}^{d}(t)-x_{i}^{d}(t)\right),
$$

burada $M_{a j}(t) j$-ci maddi nöqtə ilə əlaqədar olan aktiv qravitasiya kütləsi, $M_{p i}(t) i$-ci maddi nöqtə ilə əlaqədar olan passiv qravitasiya kütləsi, $G(t)$ zamanında qravitasiya sabiti, $\varepsilon$ kiçik sabit, $R_{i j}(t) i$ və $j$ maddi nöqtələri arasında olan Evklid məsafəsidir.

$$
R_{i j}(t)=\left\|X_{i}(t), X_{j}(t)\right\|_{2}
$$

Alqoritmə stoxastik xarakteristika vermək üçün fərz olunur ki, $d$-ci ölçüdə $i$-ci maddi nöqtəyə təsir edən ümumi qüvvə digər maddi nöqtələrə tətbiq olunan qüvvələrin $d$-ci komponentlərinin təsadüfi ağırlıqlı cəminə bərabərdir:

$$
F_{i}^{d}(t)=\sum_{j=1, j \neq i}^{N} \operatorname{rand}_{j} F_{i j}^{d}(t)
$$

$\operatorname{rand}_{j}[0 ; 1]$ intervalında təsadüfi ədəddir.

Beləliklə, $t$-ci vaxt və $d$-ci istiqamətdə $i$-ci maddi nöqtənin təcili hərəkət qanunu ilə aşağıdakı kimi hesablanır:

$$
a_{i}^{d}(t)=\frac{F_{i}^{d}(t)}{M_{i i}(t)},
$$

burada $M_{i i}(t) i$-ci maddi nöqtənin ətalət kütləsidir. 
Bundan başqa, bu təcilə əlavə olaraq maddi nöqtənin növbəti sürəti cari sürət fraksiyası kimi nəzərdə tutulur. Buna görə də, onun sürəti və mövqeyi aşağıdakı kimi hesablanır:

$$
\begin{aligned}
& v_{i}^{d}(t+1)=\operatorname{rand}_{i} \times v_{i}^{d}(t+1) \\
& x_{i}^{d}(t+1)=x_{i}^{d}(t)+v_{i}^{d}(t+1)
\end{aligned}
$$

rand $_{i}[0 ; 1]$ aralığında müntəzəm paylanmış təsadüfi kəmiyyətdir. $\mathrm{Bu}$ təsadüfi ədəddən axtarışın təsadüfi xarakteristikasını müəyyən etmək ü̧̈ün istifadə olunur.

$G$ qravitasiya sabiti $G_{0}$ başlanğıc qiymət və $t$ zamanının funksiyasıdır:

$$
G(t)=G\left(G_{0}, t\right)
$$

Qravitasiya və ətalət kütlələri yararlılıq qiymətləndirilməsi ilə hesablanır. Ağır kütlə daha səmərəli hesab olunur. Bu o deməkdir ki, daha yaxşı maddi nöqtələr asta hərəkət edirlər. Qravitasiya və ətalət kütlələri aşağıdakı tənliklər vasitəsilə yenilənir:

$$
\begin{aligned}
& M_{a i}=M_{p i}=M_{i i}=M_{i}, i=1,2, \ldots, N \\
& m_{i}(t)=\frac{f i t_{i}(t)-\operatorname{worst}(t)}{\operatorname{best}(t)-\operatorname{worst}(t)} \\
& M_{i}(t)=\frac{m_{i}(t)}{\sum_{j=1}^{N} m_{j}(t)}
\end{aligned}
$$

$f i t_{i}(t) i$-ci maddi nöqtənin $t$-ci vaxtda yararll1ıq qiymətidir. $\operatorname{worst}(t)$ və $\operatorname{best}(t)$ aşağıdakı kimi müəyyən olunur (minimallaşdırma məsələsi üçün):

$$
\begin{aligned}
& \operatorname{best}(t)=\min _{j \in\{1,2, \ldots, N\}} f i t_{j}(t) \\
& \operatorname{worst}(t)=\max _{j \in\{1,2, \ldots, N\}} f i t_{j}(t)
\end{aligned}
$$

Qeyd edək ki, bu maksimallaşdırma məsələsi üçün aşağıdakı kimi hesablanır:

$$
\begin{aligned}
& \operatorname{best}(t)=\max _{j \in\{1,2, \ldots, N\}} f_{j i}(t) \\
& \operatorname{worst}(t)=\min _{j \in\{1,2, \ldots, N\}} f i t_{j}(t)
\end{aligned}
$$

Lokal optimaldan qaçmaqdan ötrü Kbest-dən istifadə olunur. Kbest zamanla azalan və başlanğıc $K_{0}$ qiyməti ilə zaman funksiyasıdır. Belə bir şəkildə, başlanğıcda bütün maddi nöqtələr qüvvə tətbiq edir və zaman keçdikcə, Kbest xətti azalır və sonda digərlərinə tətbiq etmək üçün yalnız bir maddi nöqtə qalır. Ona görə də, $F_{i}^{d}(t)=\sum_{j=1, j \neq i}^{N} \operatorname{rand}_{j} F_{i j}^{d}(t)$ bərabərliyi aşağıdakı şəkildə modifikasiya olunur:

$$
F_{i}^{d}(t)=\sum_{j \in \text { Kbest }, j \neq 1} \operatorname{rand}_{j} F_{i j}^{d}(t)
$$

Qara dəlik alqoritmi: 18-ci əsrdə Con Mişel və Pyer Laplas qara dəliklərin konsepsiyasını müəyyən edən qabaqcıllardan olmuşlar. Nyuton qanunun inteqrasiyası ilə onlar gözə görünməz ulduz nəzəriyyəsini formalaşdırdılar və bu dövr ərzində o qara dəlik kimi tanınmırdı, yalnız 1967-ci ildə Amerikan fiziki Con Uiller ilk dəfə olaraq kütlə dağılışı fenomenini qara dəlik adlandırdı [8].

Ümumi nisbilik nəzəriyyəsinə görə, qara dəlik hər hansı cisim güclü sıxılarkən yaranan obyektdir. Bu zaman cazibə sahəsi o qədər güclü olur ki, işı̆̆ı, ümumiyyətlə şüalanmanı və ya hissəcikləri buraxmır. Cisim bütün istiqamətlərdə qravitasiya radiusundan kiçik ölçüyədək sıxıldıqda qara çuxur yaranır. Qara dəliyin (hans1 cisimdən yaranmasından asılı olmayaraq) xarici qravitasiya sahəsi kütlə, hərəkət miqdarı momenti və elektrik yükü ilə təyin edilir. Qara dəliyin ətrafında - güclü qravitasiya sahəsində fəzanın həndəsəsi qeyri-Evklid həndəsəsidir, zaman isə belə cazibə sahəsi olmayan yerə nisbətən yavaşıyır. Qara dəlik hərəkət miqdarı momentinə malikdirsə, onun yaxınlığındakı bütün cisimlər qara dəlik ətrafina firlanma hərəkətinə cəlb edilmiş olur. Maddə və şüa qara dəliyə ancaq daxil ola bilər, oradan isə çıxa bilməz. Kənar müşahidəçi qara dəliyə düşən maddədə nə baş verdiyini heç vaxt bilmir. Fəzada qara dəlik böyük ölçülü ulduzlar çökdükdə formalaşır. Qara dəliklərin qravitasiya gücü çox yüksəkdir. Qravitasiya o qədər güclüdür ki, materiya kiçik bir məkana sıxışdırılmışdır. Maddə və şüa qara dəliyə ancaq daxil ola bilər, oradan isə çıxa bilməz. Kənar müşahidəçi qara dəliyə düşən maddədə nə baş verdiyini heç vaxt bilmir. Fəzada qara dəliyin kürəşəkilli sərhədi üfüq hadisəsi kimi tanınır. Üfüq hadisəsinin radiusu Şvarş̧ilda radiusu adlanır. Bu radiusda hərəkət sürəti uçuş sürətinə bərabərdir. Üfüq hadisəsinin daxilindən heçnə qurtula bilməz, çünki işıq sürətindən daha sürətli hərəkət edə bilən heçnə yoxdur. Şvarsşilda radiusu aşağıdakı tənliklə hesablanır:

$$
R=\frac{2 G M}{c^{2}},
$$

burada $G$ qravitasiya sabiti, $M$ qara dəliyin kütləsi və $c$ işıq sürətidir.

Alqoritm: Qara dəlik alqoritmi digər çoxluq əsaslı alqoritmlərin ümumi xüsusiyyətlərinə malik çoxluq əsaslı alqoritmdir. Digər çoxluq əsaslı alqoritmlər kimi, verilmiş məsələ üçün namizəd həllər çoxluğu yaradılır və axtarış fəzasında təsadüfi paylanır. Çoxluq əsaslı alqoritmlər müəyyən mexanizmlər vasitəsilə optimal həllə doğru yaradılan çoxluğu inkişaf etdirir. Qara dəlik alqoritmində çoxluğun inkişafi hər iterasiyada bütün namizədlərin ən yaxşı həllə doğru hərəkəti ilə həyata keçirilir. Qara dəlik terminologiyası ilk dəfə etalon funksiyanın həllində istifadə olunmuşdur. Bu alqoritmdə hər iterasiyada bütün namizəd həllər arasında ən yaxşı həll qara dəlik vo nizamlı ulduzlardan digər bütün namizəd həllər kimi seçilir. Qara dəliyin yaradılması təsadüfi deyil və bu çoxluğun real namizədlərindən biridir. Sonra bütün namizədlər onların hazırkı yeri və təsadüfi sayı əsasında qara dəliyə doğru köçürülür. Qara dəlik alqoritminin əsas xüsusiyyətləri aşağıda göstərilmişdir:

Digər çoxluq əsaslı alqoritmlərə oxşar olaraq qara dəlik alqoritmində namizəd həllərin-ulduzların təsadüfi yaradılmış 
çoxluğu problem və ya funksiyanın axtarış fəzasında yerləşdirilir. İnisializasiyadan sonra çoxluğun yararlılıq qiymətləri hesablanır və çoxluqda ən yaxşı yararlılıq qiyməti olan ən yaxşı namizəd həll qara dəlik kimi seçilir və qalanlar nizamlı ulduzları formalaşdırır. Qara dəlik onu əhatə edən ulduzları udmaq imkanına malikdir.

Qara dəlik və ulduzların inisializasiyasından sonra qara dəlik onun ətrafinda olan ulduzları udmağa başlayır və bütün ulduzlar qara dəlik istiqamətində hərəkət etməyə başlayır. Qara dəlik tərəfindən ulduzların udulması aşağıdakı şəkildə ifadə olunur:

$$
\begin{gathered}
x_{i}(t+1)=x_{i}(t)+\operatorname{rand} \times\left(x_{B H}-x_{i}(t)\right) \\
i=1,2, \ldots, N
\end{gathered}
$$

burada $\quad x_{i}(t)$ və $x_{i}(t+1) t$ və $\quad t+1$-ci iterasiyada $i$-ci ulduzun mövqeləridir və müvafiq olaraq $x_{B H}$ axtarış fəzasında qara dəliyin mövqeyi, rand $[0 ; 1]$ aralığında müntəzəm paylanmış təsadüfi ədəddir. $N$ ulduzların (namizəd həllərin) sayıdır. Qara dəliyə doğru hərəkət edərkən ulduz qara dəlikdən daha aşağı qiymət ilə mövqeyə çata bilər. Belə olan halda, qara dəlik ulduzun mövqeyinə doğru və əksinə hərəkət edir. Sonra qara dəlik alqoritmi yeni mövqedə qara dəlik ilə davam edir və ulduzlar bu yeni mövqeyə doğru hərəkət etməyə başlayır.

Bundan başqa, qara dəliyə doğru ulduzların hərəkəti zamanı üfüq hadisəsinin keçid ehtimalından istifadə olunur. Qara dəliyin üfüq hadisəsindən hər bir ulduz (namizəd həll) keçən zaman qara dəlik tərəfindən sorulur. Hər dəfə namizəd həll (ulduz) ölür-qara dəlik tərəfindən sorulur-başqa namizəd həll yaranır və axtarış fəzasında təsadüfi paylanır və yeni axtarışa başlayır. Bu namizəd həllərin sayını sabit saxlamaq üçün həyata keçirilir. Bütün ulduzlar köçürüldükdən sonra növbəti iterasiyaya keçilir.

Qara dəlik alqoritmində üfüq hadisəsinin radiusu aşağıdakı kimi hesablanır:

$$
R=\frac{f_{B H}}{\sum_{i=1}^{N} f_{i}}
$$

$f_{B H}$ qara dəliyin yararlılıq qiyməti, $f_{i} i$-ci ulduzun yararlılıq qiymətidir. $N$ ulduzların (namizəd həllərin) sayıdır. Qara dəlik ilə namizəd həll arasındakı məsafə $R$-dən kiçik olarsa, namizəd həll çökür və yeni namizəd həll yaradılır və axtarış fəzasında təsadüfi paylanır.

\section{DİGӘR ALQORİTMLӘR}

Tədqiqatçılar yeni alqoritmləri işləyən zaman onlardan bəziləri təbiətdən kənar mənbə axtara bilər. Nəticədə, bəzi alqoritmlər bioloji və ya fizika-kimya əsaslı olmur və bu alqoritmləri bəzi vaxtlarda bu 3 kateqoriyaya daxil etmok çətin olur, çünki bu alqoritmlər sosial, emosional və s. kimi müxtəlif mənbələrin müxtəlif xarakteristikalarından istifadə etməklə işlənilir. Buna görə də onları digər kateqoriyaya aid etmək daha yaxşıdır. Bu alqoritmlərə Diferensial Axtarış,
İmperialist rəqabət, Sosial emosional optimallaşdırma alqoritmləri və s. daxildir.

İmperialist rəqabət alqoritmi: İmperializm öz hüdudlarından kənarda imperiya gücünün yayılması siyasətidir [9]. İmperialist birbaşa qayda üzrə və ya mal və xammal bazarına nəzarət kimi dolayı vasitə ilə digər ölkələr üzərində hakimlik edir.

İmperialist Rəqabət Alqoritmi (İRA) son vaxtlar müxtəlif optimallaşdırma məsələlərinin həlli üçün qəbul edilmiş ictimai-siyasi motivli qlobal axtarış strategiyasıdır. Bu alqoritm süni neyron şəbəkəsinin optimal çəkisini tapmaq üçün istifadə olunur.

Oxşar təkamül alqoritmləri kimi, İRA mümkün məkanda təsadüfi yaranan ölkələrin ilkin çoxluğu ilə başlayır. Hər bir ölkə country $=\left[p_{1}, p_{2}, \ldots, p_{N}\right]$ vektoru ilə təsvir olunur. Burada, $N$ optimallaşdırma məsələsinin ölçüsüdür. Vektorun hər bir dəyişəni ölkənin ictimai-siyasi xarakteristikası ilə izah oluna bilər. $\mathrm{Bu}$ baxımdan, alqoritm "mədəniyyət", "dil", "iqtisadi siyasət" və hətta "din" kimi sosial-siyasi xüsusiyyətlərin ən yaxşı kombinasiyasından ibarət olan ən yaxşı ölkəni tapmağa çalışır. Optimallaşdırma baxımından bu problemin on az maya dəyəri ilə həllini tapmağa gətirib çıxarır. Başlanğıc çoxluğun ən yaxşı ölkələri onların məqsəd funksiyasını nəzərə alaraq imperialist ölkələr, yerdə qalanlar isə bu ölkələrin müstəmləkələri hesab olunur.

Hər bir ölkənin dəyəri aşağıdakı funksiya vasitəsilə təyin olunur:

$$
c_{i}=f\left(\text { country }_{i}\right)=f\left(p_{i 1}, p_{i 2}, \ldots, p_{i N}\right)
$$

Yuxarıda qeyd etdiyimiz kimi alqoritm ilkin olaraq $N$ ölkə ilə başlayır, onların arasında ən yaxşı $N_{i m p}$ imperialist olaraq seçilir. Yerdə qalan ölkələr müstəmləkələr olaraq seçilir.

Başlanğıc imperiyaları qurmaq üçün müstəmləkələr imperialistlərin gücü əsasında onlar arasında bölünür. İmperiyanın müstəmləkələrinin ilkin sayı bilavasitə onun gücünə mütənasib olmalıdır. Müstəmləkələri imperiyalar arasında proporsional olaraq bölmək üçün imperiyanın normallaşmış dəyəri aşağıdakı kimi müəyyən olunur:

$$
C_{n}=\max _{i}\left\{c_{i}\right\}-c_{n}
$$

$c_{n} n$-ci imperiyanın dəyəri və $C_{n}$ isə normallaşmış dəyərdir. Bunun əsasında hər bir imperiyanın normallaşmış gücü müəyyən oluna bilər:

$$
p_{n}=\left|\frac{C_{n}}{\sum_{i=1}^{N_{\text {imp }}} C_{i}}\right|
$$

İmperiyanın müstəmləkələrinin ilkin sayı aşağıdakı düstur vasitəsilə müəyyən olunur:

$$
N C_{n}=\operatorname{rand}\left\{p_{n} .\left(N_{c o l}\right)\right\}
$$


burada $N C_{n} n$-ci imperiyanın müstəmləkələrinin ilkin say1, $N_{c o l}$ isə müstəmləkələrin ümumi sayıdır. Müstəmləkələri imperiyalar arasında bölmək üçün başlanğıc mərhələdə $N C_{n}$ təsadüfi seçilir. Daha sonra imperiyalar bu müstəmləkələrə öz gücləri hesabına sahib olurlar. İmperiyanın ümumi gücü həmin imperiyanın dəyəri ilə onun müstəmləkələrinin dəyərinin ədədi ortasının (mean) cəminə bərabərdir və aşağıdakı düsturla müəyyən olunur:

$$
T C_{n}=c_{n}+\operatorname{emear}\left\{\cos t\left(N C_{n}\right)\right\}
$$

burada $T C_{n} n$-ci imperiyanın ümumi gücü və $\varepsilon \in[0 ; 1]$ aralığında qiymət alanmüsbət ədəddir.

İmperiyalar arasında rəqabət aşağıdakı düsturla təsvir olunur:

$$
\begin{gathered}
N T C_{n}=\max _{i}\left\{T C_{i}\right\}-T C_{n} \\
p_{p_{n}}=\left|\frac{N T C_{n}}{\sum_{i=1}^{N_{\text {imp }}} N T C_{i}}\right|
\end{gathered}
$$

burada $N T C_{n} n$-ci imperiyanın normallaşmış ümumi dəyəri, $p_{p_{n}} n$-ci imperiyanın müstəmləkələrə sahibolma ehtimalıdır və $\sum_{i=1}^{N_{\text {imp }}} p_{p_{i}}=1$.

Rəqabət başladıqdan sonra hər hansı bir imperiya uğur qazana bilmədikdə və gücünü artıra bilmədikdə o rəqabətdən uzaqlaşdırılır. Rəqabətin nəticəsi olaraq güclü imperiyaların gücü artacaq, zəif olanlarda isə azalacaq. Zəif imperiyalar gücünü itirərək dağılacaq. Sonda müstəmləkələrin müvafiq imperialistlərə doğru hərəkətindən və həmçinin tənəzzül mexanizmindən istifadə edərək bir imperiya optimallaşdırma məsələsinin həlli olacaq.

\section{NӘTICӘ}

Təbiət əsaslı alqoritmlər çevikdir və dəyişən mühitdə işləyirlər. Bu alqoritmlər çox mürəkkəb məsələrin həllində yüksək keyfiyyətə malikdirlər və onlar vasitəsilə olduqca yaxş1 nəticələr əldə olunur. Onlar müxtəlif mühitlərdə mümkün həlli tapmağa çalışır və çox yaxşı qərarlar qəbul edirlər. Miqyaslanma problem deyil. Amma digər tərəfdən, təbiət əsaslı sistemləri hazırlamaq çox çətindir, belə ki, alqoritmlər təbiətdən ilham alınaraq yaradılır və təbiətin anlaşılması bütövlükdə mürəkkəb prosesdir. Təbiətə əsaslanan sistemlər miqyaslanma və məhsuldarlıq baxımından real sistemə (dünyaya) tam uyğunlaşmır. Sistemlər müəyyən sahədə yaxşı işlədiyi halda, digər sahədə yaxşı işləməyə bilər. Sistemlər təbiətdən ilham alınaraq yaradıldığından dəqiq təbiət biliyinə sahib olmamaq alqoritmin dizaynına təsir edə bilər. Bu alqoritmlər öz-özünü öyrətmə, öz-özünü hazırlama, özünü təşkil etmə və özünü inkişaf etdirmə qabiliyyətinə malikdirlər.
Onlar təbiətin sadə qaydalarından istifadə edərək mürəkkəb problemlərin optimal həllini tapa bilərlər.

$\mathrm{Bu}$ sahəkifayət qədər tədqiq edilməmişdir və bir sıra boşluqlar mövcuddur. $\mathrm{Bu}$ sahə üzrə geniş tədqiqatların aparılmasina ehtiyac var.

\section{ӘDӘВIYYAT}

[1] Z.W. Geem, J. H. Kim, and GV Loganathan, "A new heuristic optimization algorithm: harmony search.”, Simulation,vol.76, no.2, pp. 60-68, 2001.

[2] X.-S. Yang, Nature-İnspired Metaheuristic algorithms, 2010.

[3] X.-S. Yang, Z. Cui, R. Xiao, A. H. Gandomi and M. Karamanoglu. Swarm Intelligence and Bio-Inspired Computation: Theory and Applications (Elsevier), pp.16-17, 2013.

[4] M. Herrmann. Natural Computing. Lecture 10: Ant Colony Optimisation.2010.http://www.inf.ed.ac.uk/teaching/courses/nat/slides/le cture10_ACO.pdf

[5] A. Mozaffari, A. Fathi, and S.Behzadipour, "The great salmon run: a novel bio-inspired algorithm for artificial system design and optimisation", International Journal of Bio-Inspired Computation, vol.4,no.5, pp.286-301, 2012.

[6] G.-W.Yan and Z.-J.Hao,"A novel optimization algorithm based on atmosphere clouds model", International Journal of Computational Intelligence and Applications, vol. 12, no.1, pp.217-220, 2013.

[7] E. Rashedi, H. Nezamabadi-Pour , S.Saryazdi, " GSA: A Gravitational Search Algorithm”, Information Sciences,vol.179, no. 13, pp. 2232 $2248,2009$.

[8] A. Hatamlou. Black hole: A new heuristic optimization approach for data clustering. Information Sciences, 2012.

[9] G. Mokhtari, A. J. Ghanizadeh, E.Ebrahimi, “Application of Imperialist Competitive Algorithm to solve constrained economic dispatch",International Journal on Electrical Engineering and Informatics, vol. 4, no. 4, pp. 553-562, 2012. 